\title{
Humanistic Spirit Education in College Basketball Physical Teaching
}

\author{
$\mathrm{Xu}$ TANG \\ Chengdu Textile College \\ Chengdu,Sichuan,611731 China
}

\begin{abstract}
The lack of humanistic spirit in college basketball physical teaching is leading to the lack of innovative capacity of college students; it is also the root causes affecting the teaching effect. In teaching process, strengthening the countermeasures of college sports humanities education, raising the awareness of humanism knowledge of college students, seizing the opportunity of education, shaping healthy humanism spirit, respecting for beauty to enhance students' aesthetic ability can promote the education of humanism in physically teaching, so as to achieve optimization of teaching.
\end{abstract}

Keywords- College basketball, humanistic spirit of sports, education

\section{THE IMPORTANCE OF A HUMANISTIC SPIRIT EDUCATION IN COLLEGE SPORTS TEACHING}

As a strong educational trend, humanistic spirit receives much attention and favor, especially in the recent Chinese sports, physical education circles, it raises big waves. The spirit culture of human is the body of humanism; it is a person's inner spirit. Humanism spirit is the thought of human survival value such as why do human alive, the performance of it is universal truth-round development of human. People-oriented, creating and express personal living ideals and value ideals are humanism spirit. Pursuit of personal development, recognizing the individual status, values, respects for their dignity have been the original intention of sports and education, it is the best embodiment of the human spirit. Humanistic education is very popular in developed countries as a main form of education, and it has received big success, yet in China there are few using, especially in physical education, it have little effect under the current realities background, the integration of physical education and humanism education becoming an urgent task in college public course, it is also the demand of the times, the requirement of talent cultivation, as well as human's own developing requirements, the unity of physical education and humanism education is an inevitable trend in the development of the modern college sports teaching.

\section{GOALS OF HUMANISM SPIRIT EDUCATION IN COLLEGE SPORTS.}

\section{A. Goals of humanism spirit destruction in college sports}

Under the guidance of sports humanistic education ideology, combine with the actual situation of university sports development, locate college sports concept, concise college sports college sports spirit and highlight the moral outlook, leading the direction of the university sports development.

\section{B. Goals of in college sports material destruction in college sports.}

college sports material destruction in college sports, including sports physical facilities, sports and cultural marks and sports media propaganda, infiltration of sports culture, it is devoted to the humanism care and improve the quality of material culture, and strive to achieve a "substance" of the people, so as to make those objective material which used to be no life be changed into glorious history of eulogizing university, and tell university educational philosophy, spirit, aesthetic appeal and value of the pursuit of "educator."

\section{College Sports institutional culture building goals}

University of Physical Culture and Education building system elements, including sports organizations, sports management system, sports tradition and culture, the implementation of one of the sports management thinking, the executive type, instruction type sporting organizations, to service-oriented, urging type conversion, cold, the rigid system of management to text humane, democratic and open way of sports management transformation, and then construct a good sports tradition and culture, promote student sporting behavior autonomy, and self-conscious.

\section{The goals of behavior cultural destruction}

Physical Behavior university culture and education building elements, including physical education, physical education teaching and campus sports activities, sports and cultural activities to create a campus atmosphere, attracting teachers and students to actively participate in sports and experience the spirit of sports, fun sports, the sports values, sportsmanship, sportsmanship, the sport into people's attitude to life norms, codes of conduct and ethics. 


\section{UNIVERSITIES BASKETBALL TEACHING STATUS AND PROBLEMS ANALYSIS}

\section{A. Old fashioned teaching methods}

The so-called teaching methods, in fact, are the total name of the means of achieving the goal of teaching or teaching tasks. In the process of conducting physical education, teaching methods is one of its main ingredients. Therefore, in order to make students to get more basketball skills and basketball knowledge in limited time, efforts to train students in basketball training, the effectiveness of teaching methods is the key to solving these problems. Reasonable teaching method can make students grasp of basketball skills and knowledge better, develop students' ability in basketball better. Teaching in a dull, stale and stylized serious way severely neglected the development of their own personality, and so teachers can not teach students at the base of their own conditions, students' learning initiation and enthusiasm basketball were severely affected.

\section{B. Unscientific appraisal methods}

Now, the evaluation of many colleges and universities basketball special curriculum are through traditional basket skill level as evaluating way, the traditional evaluation methods seriously neglected the basic physical differences of individual, affect test results in a large part, it can easily lead to the phenomenon that students only learn what is tested in exam, especially for those students with poor base, this phenomenon is more serious. In addition, for many students who are not in high activity level, they usually do targeted exercises, in order to get a high score, while those with high levels of student sports basketball scores lower than them, this situation does great harm for students to improve ability and develop excising habit

\section{SITUATION OF HUMANISTIC SPIRIT EDUCATION IN COLLEGE BASKETBALL TEACHING}

\section{A. Too simple physical education goals}

Currently, the goal of teaching in college sports is a single hand, we overemphasize the goal of strengthening physical ability, just focus on mastering the skills, but largely ignored the cultivation of students' emotions and capabilities. On the other hand, the current PE teaching on their own position is not accurate enough, too much emphasis on physical education school their social properties to uniform requirements to measure student development, unified set of goals for students, not only limits the students to pursue different goals also affect the direction of their lives and outlook on life is established for the development of individual students played a serious impediment.

\section{B. Content of the examination of Physical Education.}

Teaching of Physical Education and culture there is the same problem that the content of the examination. Physical education is not to improve the physical fitness of students, develop students' awareness of healthy living for the subject, but merely to emphasize athletic events, ignoring the psychological needs of students, making physical needs and psychological needs of the students there are differences in physical education, thus making sports the movement lost its goal to promote physical and mental health development.

\section{Problems of sports teaching methods}

Physical Education put sports training, sports skills acquisition in the first place, emphasizing student uniform set of technical mastery, put one-sided emphasis on accurately place the action, uniform, serious neglect of students to develop self-initiative, so that students' enthusiasm of learning greatly reduced. The criteria to evaluate the physical education lack uniform provisions, not only ignored individuals' differences, but also ignored the ability of the student body as well as the progress that physical education became mechanized body training.

\section{School leaders are lack of knowledge in sports}

From the perspective of sports humanistic sociology we know that college sports humanistic spirit is still in the weak link, it is basically a blind spot. For decades, sports humanistic spirit of university education is always the incarnation of sports culture, and sports culture from the perspective of understanding human spirit is also relatively simple, they think by improving the cultural quality of the human, spirit can be improved. This understanding restricted the development of education in college sports humanistic spirit to a great extent, which restricts the development of higher education.

\section{E. Education personnel quality of training specifications is not enough}

Teachers are lack of knowledge of sports humanistic spirit .Under the current context, the integration of physical education and humanistic spirit of education be placed in front of physical education and an urgent task: "integration of physical education and humanity education is inevitable demand of the times, the requirement of talent cultivation, but also the need for human's own development. "Physical education and humanity education unity is an inevitable trend of modern college physical education. Some physical education teachers think that physical education has always emphasized technical training school sports, most are only interspersed with some sports and cultural knowledge, training or guidance on specific human spirit is very simple.

\section{F. Weak consciousnesses of college students training for sports humanistic spirit}

College students are still affected by traditional sports concept, most students still remain thinking "heavy wisdom, light body" and the understanding of the sport just to stay on the surface, but can not go deeper understanding of sports humanistic spirit, the pursuit of sports humanistic spirit is the essence of sports. 


\section{MEASURES OF IMPROVING TEACHING BASKETBALL SPORTS HUMANISTIC SPIRIT}

\section{A. Changing Sports concept, establish a "people-oriented" college sports aesthetic concept}

The real power of sport is rooted in the great sport of humanistic spirit of philosophy, values, among sports. Because the human spirit is the essence of sports power of sport, it is the starting point of the possibility of human development, in order to care for the full and harmonious development of the human heart and the highest goal, university sports reshape the human spirit, changing sports concept, it is extremely important to the education department and the university leadership level to put the concepts into the core. To grasp the spirit of college sports, history and civilization heritage, we must establish a correct concept of modern sports. That is to say, we have to adjust the values, beyond the utilitarian, to establish a "peopleoriented" concept of modern college sports as the goal, to promote the human body and mind, the full and harmonious development of society.

\section{B. To strengthen the importance of reshaping the human spirit again}

As a special education institutions, university act both as a matter of objective existence and a spiritual existence, it concerns human liberation, human development and human perfection as the theme, and locate nature talent as a fundamental task, not only to teach students knowledge and ability to adapt to the society, the most important thing is to cultivate spiritual. Domestic and foreign academics in understanding the nature of university education, higher education has been the profound knowledge as a logical premise, profound knowledge of the existence of legalized judgment based university, is the most essential for university education reflects that their college education is profound knowledge institutions, it is clear that knowledge is not profound expertise.

\section{Strengthening countermeasures of college physical culture}

College physical education should change the concept and make physical education and humanistic education integration. For a long time, the concept of physical education college sports is physical fitness and is an important means to develop the character of college life of hard work, this single, conservative sports concept, has seriously hampered the development of college physical education. Thus, college sports should change concepts of education, with the times, to find the point of integration of physical education and humanistic education, physical education can make a better integration of education and humanities.

\section{Leading college students to raise awareness of human knowledge}

Currently, a major university sports curriculum courses and two forms of rational perish practical classes will be a combination of both organic mode of education is to train new college humanities knowledge. In sports theory class, teachers should strengthen the humanities of college students, enrich knowledge of college students, make university students improve cultural cognition. Practical classes in sports, physical education teachers can put humanistic knowledge into some games, so that students master the knowledge of the humanities in the joy of the game. PE teachers can also use modern teaching methods, this will produce the image of human knowledge into intuitive courseware, let college students analyze and value the important role of human knowledge in Physical Education. Therefore, physical education teachers can enrich human knowledge of college students through various means to improve college students' humanities, so as to improve the aesthetic appeal of university students, to raise awareness of human knowledge thinking of university students.

\section{E. Highlight the humanistic value of a healthy body, and enhance students' sense of responsibility}

In sports teaching process of school, they presented a deeper reality, which is the body - health - life, the recognition of life and life chain has been considered to be no longer belongs to the family; it has expanded to belong to social level. This makes students to re-recognize the value of their own bodies in new perspective. In other words, we should recognize that their own health care, health care for others and the whole community health blending society for ourselves and others are highly humanistic values,being responsible for their own health is also being responsible for the family, for society, for the country.

\section{F. Seize the opportunity of education, shaping healthy humanism spirit}

Seize the golden opportunity in focusing on humanism education , at the same time of carrying out the process of the games should fully reflect the humanism education, namely to carry out the Games emblem design, sports quiz, debate team, sports keynote speech contest. The various activities undertaken games tiled penetrate into various time periods, to encourage and help students to organize various forms of activities to keep them in school under the aegis of their own sports organizations will, be included in the competition program school groups, providing the necessary technical guidance and support in all aspects.

\section{G. Advocating noble education, to enhance students' aesthetic ability}

Beauty, as the harmonious development of the human personality and spiritual synthesis flag, resides in a wide range of moral, intellectual, physical being. For example, in 
teaching gymnastics skills, the teacher's actions demonstrate perfect, graceful movements and gestures, virtually give students the confidence and courage to enhance learning.

\section{CONCLUSIONS}

When in basketball teaching, at the same time of teaching technical skills to students, it should also be taught to students that sports humanistic spirit of the human spirit and the sport of basketball practice, to enhance students' understanding of the macro basketball, understand education culture, physical culture, health and cultural heart of culture and entertainment, and thus enhance the awareness of basketball, enrich basketball emotional, moral respect of basketball, pursuit of basketball, establish basketball thinking, in order to cultivate students' ability to participate in the life of basketball, basketball literacy to improve the achievement of students .

\section{REFERENCES}

[1] Liu Fey ping, Gong Quiz Ling. Sports Humanistic Spirit Education of College Basketball Teaching [J]. New West (latter half), 2008,03:164 +163 .

[2] Liu Fei ping, Gong qiu Ling. On the cultivation of sports humanistic spirit and basketball teaching students' creative ability[J]. Chemical Higher,2009, 05:100-102.

[3] Liu Fang. On the Reconstruction of College Physical Education and Sports humanistic spirit [J]. Chi feng College (Natural Science), 2012, 11:88-89.

[4] Tong Yu fei. Research on university students' Physical Training of the human spirit[D]. Southwestern University, 2013. 